\title{
THE ISSUE OF CULTURAL DIVERSITY AND TOLE- RANCE IN MODERN GEORGIAN POLITICS
}

\author{
MANANA DARCHASHVILI \\ Georgian Technical University \\ 77, Kostava str., 0160, Tbilisi, Georgia \\ E-mail address: mananadarchashvili@gmail.com \\ ORCID: https://orcid.org/0000-0002-7414-5160
}

\begin{abstract}
Aim. Georgia has traditionally been a country of cultural diversity. Due to the proper political approach, Georgian authorities of all times have managed to successfully govern the peaceful coexistence of people of different nationalities and religions. It is true that in the post-Soviet period, there was some disagreement between the cultures inspired by external forces; however, generally, all the authorities made every effort to legally strengthen the inherited tolerant habit. The paper does not deal with the conflicts of ethnopolitical nature, staged by Russia. The mentioned issue is a part of the country's domestic policy, which is important and still is relevant nowadays, therefore the paper aims to study the role of cultural diversity and tolerance in modern Georgian politics, the attitude to it, and how the country managed to preserve the centuries-old heritage.

Methods. Based on several empirical materials, various researched-studied documents, scientific papers, analysis of government documents, the use of the method of historicism is presented in the paper.

Results. The paper presents the current existing reality in Georgia in the field of cultural diversity and the effective steps of the state for the proper development of cultural diversity.

Conclusion. Modern Georgian politics is motivated to involve ethnic and religious minorities in the process of monitoring and implementing the Culture Policy Action Plan, based on the recent history and new current worldwide tendency, which will guarantee the establishment of a tolerant society and democracy in Georgia.
\end{abstract}

Key words: Georgia, cultural diversity, politics, tolerance, state

\section{INTRODUCTION}

Ceorgia is a country of different cultural diversity, with people of various

Jethnic and religious backgrounds living alongside for centuries. The peaceful coexistence of its citizens has always been considered as one of the most important challenges in the country's domestic politics. 
Georgian authorities have at all times tried to continue the tradition of peaceful coexistence in the country, taking into account the existing cultural diversity, which meant respecting different ethnic and religious representatives. This is the reason to study cultural diversity and the correct definition and perception of future cohesion in the country have always been relevant. Due to the urgency of cultural diversity, tolerance is very topical for the country, and accordingly, many Georgian researchers and scholars have presented their interesting works and textbooks about it (Chiabrishvili, Gakheladze, Maghlakelidze, \& Malazonia, 2016).

It is necessary to mention the book Cultural Roots Management: from theory to practice published in 2017, which is the consistent guideline for the cultural routes of the Council of Europe and underline the importance of polyhedral European identity. The book is presented as an important tool for intercultural dialogue and is considered as a guidebook for route managers, cultural tourism, and other stakeholders (Antidze, 2017).

The policy paper Culture for All - an Indicator for Economic Development and International Cooperation discusses issues which include: the involvement of ethnic and religious minorities in the civil sector and monitoring and implementing cultural policy and action plans; as well as the protection and promotion of cultural diversity; the presence of ethnic minorities cultures and its role in the country's development, as well as culture and the creative industry, equal access to culture in the capital and/or in the suburbs, etc. (Galdava, Solomonia, \& Solomonishvili, 2016).

It is noteworthy to mention that in addition to scientific research papers regarding our topic due to the importance of cultural diversity, several significant documents have been developed and adopted, which can be considered as guiding principles in the country. The research question is the following whether cultural diversity is respected in modern Georgian politics and if the issue of tolerance fits the frame of democracy requirements.

The paper deals with the issue of cultural diversity and tolerance in modern Georgian politics. The possibilities of peaceful co-existence and co-operation in a multinational and multi-confessional country, the identification of hindering factors, and development of recommendations.

The research hypothesis - centuries-old multicultural heritage, with its characteristic tolerance, is an important challenge for modern Georgian politics, trying to develop the experience gained from the past following one of the basic principles of modern democratic - tolerance.

It should be noted that in this regard we consider the Georgian reality according to the scientifically stated three main types of cultural interaction (confrontation, symbiosis, and synthesis) we can claim that we have symbiosis. Here, alongside the "local" main culture, all the cultures maintain their validity.

The decision about establishment of the Department of Intercultural Dialogue in Tbilisi State University, taken at the Vilnius Conference Civilization Dialogue and the Caucasus, in 2003 (which is functioning since 2006) can be 
considered as an issue of great importance for such multinational states as Georgia since it represents a solid base to promote the country's cultural policy and conduct intercultural dialogue. It is noteworthy to say that the above mentioned Department of Intercultural Dialogue functioning at Tbilisi State University has been accepted as a member of the United Nations Educational, Scientific and Cultural Organisation/University Twinning and Networking, Institute of Cultural Sciences, Department of Interreligious Dialogue UNESCO, the department was headed by Professor Nino Chikovani and the numerous projects implemented by the department are the proof of the promotion of intercultural and interreligious dialogue.

\section{CULTURAL DIVERSITY AND TOLERANCE AS A SIGNIFICANT CHALLENGE FOR THE GEORGIAN GOVERNMENT}

An important challenge for modern Georgian politics is the strengthening of democratic institutions, which can only be achieved through cooperation with the leading international organizations and consultations with developed partner countries.

Georgia, which situates at the crossroads of East and West, even during the period of the country's political-economic-cultural prosperity paid great attention and cared for its multicultural heritage. Since the country's authorities understand that tolerance has always been an important guarantee of the multi-ethnic and multi-confessional country's success. It is well known that all the nations have three branches of culture: material, mental, and spiritual-moral, and that their integrity creates a national culture.

Georgian culture naturally developed alongside the history of the country, with the traditions of the ancient Georgian script creating a national culture, the peculiarity of which is that despite the existence of other cultures over the centuries, it maintained its individuality and did not hinder the development of other cultures. On the contrary, the abundance of ethnicities, languages , and religions imposed a special obligation on Georgia, there has always been an attempt not to limit this diversity, and according to the modern politics of peace, this diversity in some cases even represents a source of attractiveness. Ethnic diversity has long been reflected in Georgian culture. Tolerance towards the differences has been a sign of Georgian culture for centuries, in this regard we can recall, Iakob Tsurtaveli's (1979) book, Torture of Shushanik, written in the 5th Century. The ancient Georgian hagiographic original work which has survived to the present day, describes the betrayal of Shushanik's husband, Varksenen's to his faith, and the adoption of Mazdeanism to win the hearts of the Persians, and the torture of his wife, Shushanik. The paper also describes the political-economic, social situation of the country, the state of the church, morals, cultural situation. The book of Ioane Sabanisdze's, Torture of Abo Tbileli, written in $8^{\text {th }}$ century is the story of an Arab boy who was tortured for the adoption of Christianity (Chelidze, 2008). 
Numerous official documents adopted by the government in modern Georgia protect and declare readiness to protect and promote diverse cultural heritage. Georgia's National Policy for Cultural Heritage respects and promotes cultural diversity.

Georgia, striving for the European integration, is considered geographically, historically, culturally and traditionally part of Europe, where the government, together with the society, is aware of the country's transformation into a European model and of the commitment that is required for cooperation (Chiabrishvili, Gakheladze, Maghlakelidze, \& Malazonia, 2017).

Georgia joined the Council of Europe Framework Convention on the Values of Cultural Heritage for the Society of Europe (FARO Convention) in 2008, according to which the promotion of the community interested in inheritance is determined.

The Strategy 25 adopted by the Ministry of Culture and Monument Protection of Georgia (2016) envisages the creation of a favorable environment and fertile ground for the protection of national heritage, cultural diversity, and a new approach.

There is no need to argue that the diversity of cultures is an important factor in the progress of humanity and confirms the need for a dialogue of cultures. Due to this fact, several events are being held under the auspices of UNESCO, which include cultural cooperation.

It is noteworthy to mention the international approach - the UNESCO Universal Declaration - on Cultural Diversity (November 2, 2001, General Conference), which aims to establish strong solidarity based on recognition of cultural diversity, understanding of human unity and strengthening intercultural exchanges.

Georgia shares the Declaration of Tolerance Principles adopted by UNESCO member states November 16, 1995, to mark this day, by the initiative of the ex-Prime Minister of Georgia, Irakli Garibashvili, European Square in Tbilisi was named Tolerance Garden Square. Which states that, the pursuit of tolerance has become even more important for member states and the international community in general (UNESDOC, 1995) because tolerance is a respect for the rich diversity of world cultures, forms of self-expression, which is a contributing factor to the establishment of universal peace. Also, Georgia accepted the 2005 UNESCO Convention on the Protection and Promotion of the Diversity of Cultural Self-expression adopted on the $33^{\text {rd }}$ Session of the UNESCO General Conference, held in 2005 in Paris, where cultural diversity is mentioned to represent features of humanity, common heritage and the promotion and protection essential to universal well-being, and additionally, cultural diversity is the driving force for the steady development of society, people and nations; which develops in a context of democracy, tolerance, social justice and respect for peoples and cultures, to ensure peace and security at the local, state and international levels (UNESCO, 2005).

In the framework of the above-mentioned research, it is necessary to mention a few recent events that have been implemented by UNESCO in Georgia 
with the active involvement of the Georgian side. Particularly, the photo contest "Silk Road has been seen through the eyes of young people", which aimed to share the impressions of the common cross-cultural heritage and dialogue between the countries of the "Silk Road" for youth travelers in the region.

The European Union and UNESCO have adopted several important projects under the Convention for the Protection and Promotion of the Diversity of Cultural Self-Expression. Support for developing countries in the framework of such a joint program - the project Development of a Creative Cluster Ecosystem funded by Georgia under the Culture for Culture (Georgian National Commission for UNESCO, 2019). We have to say that it is a complex Convention and to receive funding for projects is quite difficult.

Last year, UNESCO celebrated the 150th anniversary of the birth of Marjorie Scott Wardrop. The meeting was held at the Library of Oxford University in the United Kingdom on the occasion of the 150th anniversary of Marjorie Wardrop's birth by the initiative of the Embassy of Georgia and with the support of the Marjorie Wardrop Foundation. Speakers noted a wide interest in Marjory's archives, which clearly shows Marjory Wardrop's aspiration for progressive ideas and change. It is noteworthy that exactly 111 years ago, Mikhako Tsereteli, a noble representative of Georgian political thought, lamented the death of Marjory Wardrop, a great supporter of Georgian culture. It is evident that in Georgian reality there has been a great interest in the culture, thus interethnic relations have always been relevant (Tsereteli, 1909).

Also, we can claim that the UNESCO Patronage of Classical Music and Jazz Festivals Georgia is very important, which gathers world-famous performers of different nationalities.

The international conference Common Heritage for Intercultural Dialogue and Development held in the National Museum with the support of the Georgian National Commission for UNESCO dedicated to the 200th anniversary of the German settlements in the South Caucasus - Azerbaijan, and Georgia, was attended by experts from Azerbaijan, Germany, Georgia, who discussed the importance of German heritage in the Caucasus in the context of the development of intercultural dialogue and underlined the traces left by the Germans in Georgian and Azerbaijani architecture, the importance of its conservation, as well as its role in the sustainable economic development of both countries.

Great attention should be paid to the exhibition Cultural Diversity and UNESCO Heritage in Georgia 2019 organized by the Embassy of Georgia in Brazil with the support of UNESCO, which represented the objects included in the list of material or intangible world heritage sites, created with a united effort of the country's multiethnic population, which shows that the tolerance has been an integral part of Georgian multiethnic population (UNESCO, 2019).

It is noteworthy that in 2005, Georgia established the Center for Tolerance in the office of the Public Defender's which is actively working to develop tolerance, cultural development, and an equal environment in the country. The center contributed significantly to the protection of ethnic and religious minorities and played a positive role in the dialogue between them. It is important 
that this unit annually rewards (with honorary diplomas, prizes) those individuals and companies who contributed to the development of tolerance and culture in Georgia. International Day for Tolerance is celebrated every year to have respect for different races and appreciate the diversity of other cultures, conduct the dialogue, create connections between cultures and civilizations. The celebration of the Day of Tolerance was adopted by UNESCO on 16 November 1995 on the Principles of Tolerance and its celebration started in 1996 by the initiative of the UN General Assembly.

It should also be highlighted that in Georgia as in one of the significant countries with cultural diversity, special attention is paid to the Universal Declaration on cultural diversity, adopted by United Nations General Assembly in 2001, which is based on the May 21, 2002, decision - to celebrate The Day of Cultural Diversity for Dialogue and Development every year (UNESCO, 2014).

The cultural diversity established in Georgia, the special respect for different cultures, including the regulation of communication, the recognition of mutual awareness and respect are still important challenges for the government. Consequently, it is considered as one of the governmental priorities.

Georgia, with its cultural diversity and distinctive tolerant skills, represents a major challenge to international interest. Since 2016, it has been a member of the Council of Europe's (Enlarged Partial Agreement) and due to its purpose, this program has been presenting different countries and cultures since 1987 in terms of common cultural heritage - cooperation in the field of culture and sharing of tourist experiences. Accordingly, it is aimed at discovering and promoting lesser-known tourist destinations and has even greater potential for developing both, the local and international cultural routes, as well as integrating transnational routes and accordingly cooperating with the Council of Europe and having more possibilities to introduce the European values.

The development of cultural diversity in Georgia is evidenced by the fact that Georgia is one of the countries which has the cultural routes, named The European Jewish Heritage Route which operates in the House of Israel in Georgia. There are other cultural routes in Georgia: the European Route of Termed Cities, the Prehistoric Rock Art Route, and the Wine Route.

While discussing cultural diversity and tolerance, it is worth mentioning that many projects and events were implemented in cooperation with the government and various organizations under the guidance of Cultural Diversity and Friendly Bridge, which makes cooperation in the field of education interesting.

In Georgia linguistic diversity is considered a very important element of culture and that education plays a significant role in the protection and development of the culture. Therefore, for those who represent the minority and indigenous peoples, Georgia has the opportunity for free development. Particularly, they have the opportunities to create, and inherit, the traditions of their cultural self-expression. Due to the multinational population in the country, there are non-Georgian language schools (Armenian-Azerbaijani) where the level of quality of education in state language - Georgian is unfortunately 
low, which should be regulated. Particularly, at the time, when the language barrier becomes a hindering factor of their integration in many local or state entities. We have to mention the challenge that COVID-19 (the spread of the deadly virus) has caused in the world. The Georgian government has once again expressed its concern for all citizens of the country, all regions (Marneuli, Bolnisi, Gardabani, and other districts), regardless of ethnic-religious culture. In this case, due to the language barrier, the government faces serious problems and requires solutions. The issue concerns the obligation of the state to provide constitutional, knowledge of the state language in the districts with non-Georgian-speaking, mixed population. However, the government succeeded in providing information and medical examinations, but the issue was still publically discussed, which stated the need to provide the population with knowledge of the state language, which will confirm the government's commitment to one of the most important signs of democracy - national equality, the establishment of tolerance.

\section{GEORGIAN POLITICAL ATTITUDE TOWARDS NATIONAL DI- VERSITY AND TOLERANCE}

The issue of national diversity and tolerance in Georgian politics, as always, occupies an important place in the country's modern stage. Since the ethnic and religious minorities, who create cultural diversity in the country, attract great attention from the side of Georgian politics. To clarify the research question, I have chosen an important component of democracy - the election process, and as the object of research - the last and most important for the Georgian reality presidential elections. To clearly understand the Georgian political spectrum (active part), the attitude of the presidential candidates toward the national minorities (pre-software applications, in fact, the expressions of their thoughts), although our objective does not represent to reveal the correlation between the promises and the executions (which is quite interesting), however, the promises written in the program documents, their political credo is very important.

From the 25 candidates running in the presidential elections of Georgia, we selected 6 candidates for the pre-election programs, based on the activities recorded during the pre-election period, with more political chances and opportunities compared to others. These candidates were: Davit Bakradze European Georgia, Grigol Vashadze - Oppositional Union, Power in Unity (Former Minister of Foreign Affairs), Salome Zurabishvili - independent Candidate (Candidate supported by the management team), Shalva Natelashvili - Labor Party (Takes part in presidential elections for the third time in 2007, 2013 and 2018), Davit Usupashvili -Builder's Movement (Former Speaker of Parliament), Zurab Japaridze - New Political Center - Girchi.

It is interesting to see how well the presidential candidates will be able to fulfill their pre-election promises in the frames of limited presidential power, 
in the case be elected as the president, and even more if they understand the possibilities of their promises in such conditions. In fact, under the conditions of parliamentary rule: the President of Georgia is not subject to the Government of Georgia and is not allowed to participate in the formation of the Government, does not have the right to resign; the President does not pursue policies in areas such as state and public security, defense, justice, economy, regional development, environmental protection.

Therefore, first of all, from the pre-election promises, we deal with the attitude of the presidential candidates towards the issue of cultural diversity and tolerance, and their attitudes.

The current president, Salome Zurabishvili is described as a guarantor of cultural heritage, an ambassador of culture, and believes that strengthening the tolerant society can be achieved through the protection and involvement of citizens of all backgrounds in the country's social and political life, and for this, the study of the state language must be accessible. At the same time, by introducing European standards and sharing Georgian culture and values in Europe, she understands the necessity of becoming a part of the European family.

It is noteworthy to say that that the pre-election programs of all the presidential candidates, which we are observing are almost identical: keywords for them are - peace, cultural development-cooperation, tolerance.

The results of the study of the presented empirical materials are obvious, well known in Georgian political spectrum presidential candidates; unequivocally acknowledge the promotion of cultural diversity, and the spirit of tolerance.

\section{CONCLUSION}

In the paper "The Issue of Cultural Diversity and Tolerance in Modern Georgian Politics" after discussing several empirical materials we concluded that the Georgian government has been trying for the past decades to maintain its traditional experience: respect, support, and cooperation with ethnic and religious minorities living in the country.

Based on the study of presented numeral documents, it becomes clear that the democratic development of the country can only be achieved through cooperation, cultural dialogue, by focusing on common mutual development, exercising granted equal rights and responsibilities.

At the modern stage of democracy, centuries-long recognition of cultures and tolerance is considered as a significant challenge to integration into the Euro-Atlantic space. The interaction of cultures in the country, the possibility and self-expression of diverse cultures, which is obvious within the country abroad, is approved by international organizations and assumed as an indicator of social progress. 


\section{RECOMMENDATIONS}

Hereby, the state should ensure the more active development of certain projects to provide the teaching of the official language in the densely populated by ethnic minority areas. To develop democracy in the country, the government should be able to raise public awareness about the importance of promoting cultural diversity. Since nowadays the promotion of cultural diversity and tolerance is of great importance and has always been one of the most important tasks that create us to be an interesting unity for the civilized world.

\section{REFERENCES}

[1] Antidze, N. (2017). The Management of Cultural Routes from Theory to Practice. Tbilisi: Typing Office for Word.

[2] Chelidze, E. (2008). Torture of Sant Abo. Volume 1. Tbilisi: Church Library.

[3] Chiabrishvili, N., Gakheladze, G., Maghlakelidze, S., \& Malazonia, D. (2016). Intercultural Education Guide. Tbilisi: Ilia State University.

[4] Chiabrishvili, N., Gakheladze, G., Maghlakelidze, S., \& Malazonia, D. (2017). Intercultural Education. Problems, their Analysis, and Development Prospects in Georgia. Tbilisi: Ilia State University.

[5] Galdava, T., Solomonia, R., \& Solomonishvili, M. (2016). Culture for All - an Indicator for Economic Development and International Cooperation (Policy Document). Georgian National Platform. Eastern Partnership Civil Society Forum.

[6] Georgian National Commission for UNESCO. (2019). Georgian project was funded within the framework of the joint program of UNESCO and the European Union. Retrieved February 3, 2020 from https:/ / unesco.ge/?p=2490

[7] Ministry of Culture and Monument Protection of Georgia. (2016).Cultural Strategy 2025. Tbilisi. Retrieved May 7, 2020 from http://www.georgianmuseums.ge/ckfinder/userfiles/ files/kulturis-strategia-2025-bolo.pdf

[8] Tsereteli, M. (1909). Miss Marjorie Wardrop. Tbilis: Georgian Moambe, \# 8.

[9] Tsurtaveli, I. (1979). Torture of Shushanik. Tbilisi: Soviet Georgia.

[10] UNESDOC. (1995). Declaration of principles and a follow-up plan of action for the United Nations Year for Tolerance. UNESCO. Executive Board, 147th session. France.

[11] UNESCO Convention. (2005). Convention on the Protection and Promotion of the Diversity of Cultural Self-Expression. Paris.

[12] UNESCO. (2014). The Fifth International Festival of Traditional Cultures and Crafts "ETHNORADUGA" devoted to the World Day of Cultural Diversity for Dialogue and Development. Kaluga Region. Russian Federation.

[13] UNESCO. (2019). Cultural Diversity and UNESCO Heritage in Georgia - Exhibition in Brazil. Retrieved February 9, 2020 from https:/ / mfa.gov.ge/ 